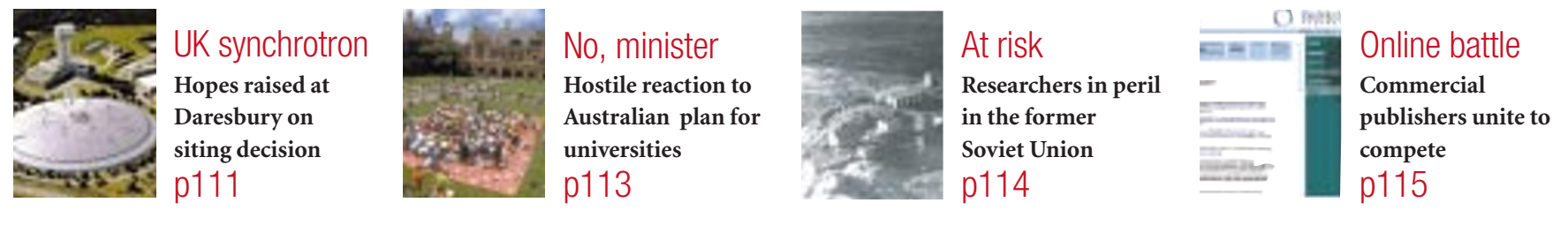

\title{
US universities find that demand for botanists exceeds supply
}

\section{San Diego}

Plant systematists, once desperate for academic jobs, have become hot property, aggressively pursued by US universities seeking to be at the forefront of biodiversity research in the new millennium.

Universities have engaged in bidding wars for leading plant systematists as if they were prized professional athletes. Some academic leaders are now concerned about balancing universities' needs for plant systematists with the available supply. "There are far too few systematists to fill available faculty positions nationally," says Brent Mishler, director of the herbaria at the University of California at Berkeley.

Plant systematists conduct a range of research, from biodiversity to genetically engineered crops. They may study the impact of climate change on flora, or identify a tropical plant from which a gene can be removed to secure a desired characteristic for an agricultural crop.

The recent completion of a 'tree of life' describing the evolutionary relationships of the Earth's green plants - by the Green Plant Phylogeny Research Coordination Group has also spurred interest in systematics, says bryologist Mishler, who is a principal investigator for the five-year project (see Nature 400, 602; 1999).

Noting that the twenty-first century is expected to be the era of the environment, Kris Krishtalka, director of the University of Kansas Natural History Museum, says: "There is going to be an enormous demand for systematists. Universities that cut faculty and students in organismal biology in the 1970s and 1980s are going to be scrambling now."

Indeed, they already are. The website for the American Society of Plant Taxonomists, whose membership of 1,300 scientists includes many of the nation's systematists (a term now virtually synonymous with taxonomists), list 15 systematics jobs at universities, herbaria and museums - a radical change from a decade ago, when plant systematists were crying out for jobs.

"The excitement of molecular biologyled to a steady reduction in the number of facul-

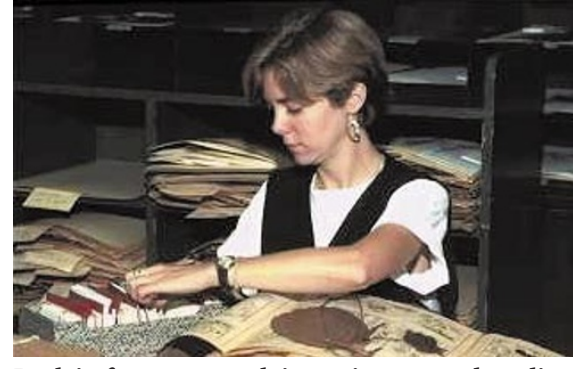

Back in favour: growth in environmental studies has rekindled demand for plant systematicists.

ty whose primary interest was in organismal biology and ecology," says Alison Richard, a primatologist who is Yale University's provost and a vociferous advocate of systematics. "That is turning around. There is growing student interest. Environmental issues have gone from having faddish, tree-hugger status to centre stage, viewed now as serious and valued.'

As part of this reassessment, Yale has recruited plant systematist Michael Donoghue to assume the G. Evelyn Hutchinson Professorship of Ecology and Evolutionary Biology on 1 July 2000. Donoghue will vacate the directorship of Harvard's herbaria - with five million specimens — for Yale's new Environmental Sciences Facility, being built next to the Peabody Museum of Natural History. The facility is to wed a variety of environmental studies with state-of-the-art molecular labs and the Peabody's 400,000specimen herbarium collection.

The wooing of Donoghue - a riveting lecturer with an encyclopaedic knowledge of the literature - came after a long courtship, in which Harvard counter-offered in an attempt to retain the popular botanist's services. "Michael has a tremendous opportunity at Yale," says Dan Hartl, chairman of Harvard's Department of Organismic and Evolutionary Biology. "He is a big loss" for Harvard, says Hartl, who noted that systematics now "is an extremely volatile area".

With the departure of Donoghue, other botanists moving elsewhere and retirements, the Harvard department is expected soon to be down by a half a dozen positions. This has concerned some doctoral graduates of the Harvard programme, such as Mishler, who says there "is a lack of appreciation of systematic biology" in some segments of the university campus. But Hartl says the "multiple recruitments" now under way provide

\section{Australia 'tops per capita emissions'}

\section{Sydney}

Australia has the highest level of per capita emissions of greenhouse gases. That was the finding of a report presented to the Australian Senate to coincide with last week's international meeting of environment ministers in Bonn.

Environmental economists at the Australia Institute used official returns to the United Nations to calculate 'carbon dioxide equivalents' by adding non-energy emissions from changes in land use, forestry and agriculture to emissions of the greenhouse gases - carbon dioxide, methane and nitrous oxide.

The research group ranked per capita emissions from the $\mathbf{3 5}$ developed nations that accepted targets to reduce emissions under the Kyoto Protocol - known as Annex B countries.

Australia scored 26.7 tonnes of emissions per capita annually - double the average of the wealthy countries in Annex B followed by the United States, Canada, New Zealand, Germany, the United Kingdom and Japan (9.5 tonnes).

Institute director Clive Hamilton says Australia has "exceptionally high emissions" from land use. Only Australia and the United Kingdom show land use as a net source of emissions. Because perceptions have been based on energy consumption, the report says, the analysis will affect the application of the 'polluter pays' principle, and exonerate Americans as the highest emitters per head of population. Peter Pockley 
"a great opportunity" to expand plant biology.

At the University of Arizona, the director of their herbarium, Lucinda McDade, is leaving to become herbarium curator at the Academy of Natural Sciences in

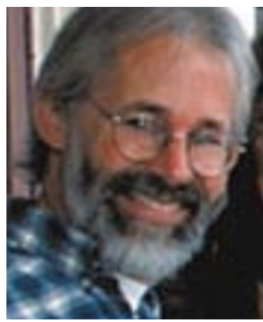

Donoghue: offered

jobs at both Harvard and Yale.
Philadelphia.

Eugene Sander, a biochemist who is dean of Arizona's College of Agriculture, says McDade had secured two National Science Foundation grants to modernize Arizona's collection of desert flora from the southwest

United States and northwest Mexico. "Our university is losing a fine scientist who will be difficult to replace," says Sander.

The University of Alaska is having trouble recruiting a director for its herbarium of high-latitude specimens, which is important for research on global warming. According to David McGuire, chairman of the Alaska search committee, when the university advertised last July for an assistant professor, it received only 15 applications, half of what was desired; and that number was achieved after pleas to herbarium directors around the nation.

Alaska is interviewing three candidates, says evolutionary biologist McGuire. Beginning today, 11 November, the American Institute of Biological Sciences, an umbrella organization for 55 biological societies, will hold a summit in Virginia for organization presidents. It will address a range of planning issues, including the availability of plant systematists, says the institute's president, Gregory Anderson, a University of Connecticut botanist.

Approximately 150 university departments of ecology and evolutionary biology include plant systematists, Anderson says. About 30 to 50 students may graduate annually, with half seeking work at universities. Consideration should be given to increasing the number of trained plant systematists - particularly those with molecular biology skills - to balance supply and demand, he says.

It is important to address this balance soon, because many plant systematists are on the verge of retirement - for example Shirley Graham, a professor at Kent State University in Ohio and president of the American Society of Plant Taxonomists.

"My husband and I are the only botanists in our department of 25 faculty, and we are both a year from retirement," says Graham. "Botanists have retired and been replaced by other disciplines. Now we have to rethink what constitutes a good programme in botany." Rex Dalton

\section{Publishing group offers peer review on PubMed Central}

Paris

The Current Science Group is to establish a new publishing house dedicated to providing peer review and other services for PubMed Central, the free repository for life-science papers that is due to be launched early in the new year by the US National Institutes of Health.

The new venture, called BioMed Central, will be established as a separate company within the group, with an initial staff of around 20. Other parts of the Current Science Group will contribute to the venture, says Vitek Tracz, the group's chief executive officer. "We have a tradition of working together as smallish, independent units with little bureaucracy, and we like it that way."

The new company, whose 'under construction' website can be viewed at http://www.biomedcentral.com/, is intended to provide a "large multidisciplinary peerreview mechanism”, sitting on top of PubMed Central that "would be equivalent to thousands of journals", says Tracz. "It is the most exciting and the most important publishing initiative I have got myself into."

On acceptance, papers submitted to Bio-
Med Central would be deposited in PubMed Central, where they would be available free to all. Tracz believes that it will be feasible to give this primary literature away, and make money from a mix of advertising, sponsorship, e-commerce and subscription to editorial material such as news and reviews.

A similar logic is being followed by a venture launched last month by the Community of Science, a private US company that gives researchers information about funding opportunities and other activities (see Nature 401, 516; 1999).

Many publishers remain sceptical whether such Internet business models largely untested in science publishing — will provide enough revenue to support quality publishing operations (see page 115).

This is partly a defensive reflex - some publishers have been making what many consider to be excessive profits (see Nature 397, 195-200; 1999). But there are genuine concerns among publishers and scientific societies that, if change is too rapid and ill-considered, the baby of quality literature might be thrown out with the bathwater.

\section{Ukraine denies arresting biologist}

\section{London}

The Ukrainian government last week denied accusations that a prominent marine biologist, Sergei Piontkovski, had been arrested and charged with sending secret information abroad and handling foreign currency illegally.

The statement was made by the first deputy foreign minister of Ukraine in response to concerns expressed by the European Commission over the arrest and detention of research workers from the Institute of Biology of the Southern Seas (IBSS) in Sebastopol (see Nature 401, 835 \& 402, 6; 1999).

Piontkovski and colleagues are back at work, but reports suggest that they still face charges, and Piontkovski's trial is scheduled for later this month. The security service continues to hold IBSS computers and documents. A spokesperson for the European aid programme INTAS said the Ukrainian Ministry of Science had been supportive in trying to persuade authorities of the innocence of IBSS staff. "It is clear to the authorities that Piontkovski was arrested on non-legal grounds," said a spokesperson.

Grants from INTAS and the British government - on biodiversity — have been the focus of inquiries by the security services. Last week, Yuri Tokarev, deputy director of the IBSS, who also faces criminal charges, said charges related to bioluminescence studies. This could be connected with the awarding of a grant by the US Office of Naval Research (ONR) to the Plymouth Marine Laboratory in the United Kingdom in August, for work with which Piontkovski is involved to create a database on bioluminescence in the oceans.

A US Navy spokesperson said: "This project is part of an international effort with broad participation and is expected to increase knowledge of the basic scientific properties of the oceans, including the distribution and abundance of bioluminescent animals and plants."

He said it would be "inappropriate" for the navy to comment on the alleged arrest, and that ONR was a "leading supporter of oceanographic research, and sponsors many unclassified basic research and datagathering projects around the world". The head of IBSS's laboratory of biophysical ecology last week said his was the only laboratory in the former Soviet Union dealing with bioluminescence in the sea. 